ORIGINAL ARTICLE

\title{
TUBERCULOSIS IN THE MUNDURUKU INDIGENOUS GROUP IN THE BRAZILIAN AMAZON: A PUBLIC HEALTH CHALLENGE
}

Laura Maria Vidal Nogueiral, Paulo Cesar Basta², Elizabeth Teixeira ${ }^{3}$ and Maria Catarina Salvador da Motta

\section{ABSTRACT}

The objective of this paper was to screen for active tuberculosis (TB), to estimate the prevalence of Mycobacterium tuberculosis (MTB), and to identify factors associated with latent tuberculosis in an indigenous population from the Brazilian Amazon. A cross-sectional study with a convenience sample of 1,213 individuals from the Munduruku indigenous group from the Tapajós River in the Jacareacanga municipality, Pará State was done. Interviews were held and tests were performed on sputum smear microscopy and culture, tuberculin skin tests (TST), and chest X-rays. The software Statistical Package for the Social Sciences was used for statistical procedures; $X^{2}$ test, univariate and multivariate analyses, $\mathrm{p}$ value $<0.05$, and $95 \%$ CI were considered. The Odds Ratio was used as an association measure. Seventy cases of respiratory symptoms were identified (5.8\% of study population), of whom one case was confirmed Mycobacterium tuberculosis (MTB) infection, achieving a punctual prevalence of 82.4/100,000. 219 chest X-rays were performed, 40 (18.3\%) of which showed abnormalities. The prevalence of TST with reactions $\geq 10 \mathrm{~mm}$ was $22.0 \%$ and $37.4 \%$ for the $5 \mathrm{~mm}$ cut-off point. The TST reactions $\geq 10 \mathrm{~mm}$ were associated with village of residence, age over 40 years, male gender, contact with a TB patient, and the presence of a BCG vaccine scar. The rate of respiratory symptoms was markedly higher when compared to the non-indigenous population. Although some adults could have been infected years previously, the high prevalence of infection and its strong association with ages under 40 years, indicate ongoing contact with TB patients.

KEY WORDS: Indigenous; latent tuberculosis infection; tuberculosis.

\section{RESUMO}

Tuberculose na etnia Munduruku da Amazônia brasileira: um desafio para a saúde pública

1. State University of Pará, School of Nursing Magalhães Barata, Belém/Pará, Brazil.

2. National School of Public Health Sergio Arouca (ENSP), Oswaldo Cruz Foundation (FIOCRUZ), Department of Endemic Diseases Samuel Pessoa, Rio de Janeiro, Brazil.

3. State University of Pará, School of Nursing Magalhães Barata, Belém, Pará, Brazil.

4. Federal University of Rio de Janeiro (UFRJ), School of Nursing, Department of Public Health Nursing, Rio de Janeiro/RJ, Brazil.

Corresponding author: Laura Maria Vidal Nogueira: Rua Veiga Cabral, 888, apto 604 B, Bairro Batista Campos, CEP: 66023-630, Belém, Pará, Brazil. Email: lauramavidal@gmail.com 
Os objetivos foram identificar sintomáticos respiratórios e casos de doença ativa, assim como estimar a prevalência de infecção latente por tuberculose (ILTB), fatores associados e descrever as características radiológicas entre pessoas com resultado de prova tuberculínica $\geq 10 \mathrm{~mm}$. Trata-se de estudo prospectivo realizado com amostra de conveniência de 1.213 indígenas da etnia Munduruku, do Rio Tapajós, município de Jacareacanga-Pará. Para obtenção dos dados, foram realizados exames diretos e cultura no escarro, prova tuberculínica e radiografias de tórax, o que permitiu a identificação de tuberculose ativa e latente. Para a análise dos dados, valeu-se do softwere Statistical Package for the Social Sciences (SPSS) com os procedimentos estatísticos: teste $X^{2}$, análises univariadas e multivariadas, nível de significância $\alpha=5 \%$ e $p$ valor $<0,05$, IC $95 \%$. Odds ratio foi utilizado como medida de associação. Foram identificados 70 sintomáticos respiratórios $(5,8 \%$ da população estudada), obtendo-se a confirmação de Mycobacterium tuberculosis com prevalência pontual de 82,4/100.000. Foram realizados 219 exames radiológicos do tórax, dos quais $40(18,3 \%)$ apresentaram alterações, sendo uma imagem cavitária. Foram realizados 1.213 testes tuberculínicos (PT) e a prevalência de infecção pelo $M$. tuberculosis (MTB) foi de $22,0 \%$ nas reações $\geq 10 \mathrm{~mm}$ e de $37,4 \%$ para o ponto de corte de $5 \mathrm{~mm}$. As reações à $\mathrm{PT} \geq 10 \mathrm{~mm}$ mostraram-se associadas com as variáveis aldeia, idade acima de 40 anos, gênero, história de contato e presença de cicatriz vacinal de BCG. São altos os índices de adoecimento quando comparados com a população não indígena. Conclue-se pelos elevados índices que alguns adultos podem ter sido infectados no passado, entretanto a associação de infecção com idade acima de 40 anos indica contato.

DESCRITORES: Indígenas; infecção tuberculosa latente; tuberculose.

\section{INTRODUCTION}

In recent decades, interest in the impact of tuberculosis (TB) in the indigenous populations in Brazil has increased. Despite being a preventable and curable disease, TB is considered a "neglected disaster" that, in most cases, affects population groups who are under privileged or paupers (Hino et al., 2011). Recent studies reveal that the degree of exposure to Mycobacterium tuberculosis remains high in these populations. In some ethnic groups, incidence rates are ten times higher than the national average (Basta et al., 2004; Bóia et al., 2009; Coimbra Jr \& Basta, 2007; Croda et al., 2012; Marques \& Cunha, 2003; Melo et al., 2012; Sousa et al., 1997), in others, drug-resistant cases (Basta et al., 2006a) and expressive prevalence rates of latent tuberculosis infection (LTBI) have been described (Basta et al, 2006b; Basta et al., 2010a; Escobar et al., 2004; Rios et al., 2013; Yuhara et al., 2013). High proportions of illness among children and adolescents (Basta et al., 2010b; Marques et al., 2010; Santos et al., 2013) have also been reported.

Data collected from the Ministry of Health (2014) indicated that the incidence of TB in Brazil in 2013 corresponded to 35.4/100,000 inhabitants. In the northern region of the country $(45.2 / 100,000)$, and particularly in Pará (44.8/100,000), the figures were higher. In 2010, the incidence rate corresponded 
to $94.5 / 100,000$ for the indigenous populations across the country and, in Pará, the levels reached 198.2/100,000. The scenario described above leaves no doubt that TB constitutes serious health issue for the indigenous people in Brazil today.

The purpose of this study was to screen for active TB, to estimate the prevalence of Mycobacterium tuberculosis (MTB), and to identify factors associated with latent tuberculosis in an indigenous population from the Brazilian Amazon.

\section{METHODS}

A cross-sectional study using a convenience sample was developed in the four largest villages of the Munduruku ethnic group in the municipality of Jacareacanga (N: $06^{\circ} 13^{\prime} 20^{\prime \prime} \mathrm{S}$; W: $57^{\circ} 45^{\prime} 10^{\prime \prime} \mathrm{W}$ ) in the Southwest of the State of Pará. According to the data from the most recent Brazilian census (IBGE, 2010), the population in Jacareacanga numbers 14,103 inhabitants, of whom 5,843 (41.4\%) consider themselves indigenous.

The Munduruku are a Tupi-speaking people, belonging to the Munduruku linguistic family, most of whom live on lands located in the states of Pará, Amazonas, and Mato Grosso, but mainly in the savannah regions located in the Amazon forest on the banks of navigable rivers. They have been strongly influenced by two sources: Economic contact, mostly coming from rubber exploitation and mining, and the religious missions, which have strongly contributed to cultural changes, introducing new forms of relationship among the indigenous people, even influencing their type of housing (Ramos, 2003).

In Pará State, the TB control actions mainly take place in the primary care network units of the Municipal Health Secretariats where: i) medical and nursing consultations take place; ii) complementary diagnostic tests are requested; iii) treatment is started; iv) medication is distributed; v) the treatment is monitored; and vi) the cases are closed.

The study context included the Nova Karapanatuba $(n=328)$, Katõ $(\mathrm{n}=430)$, São Francisco Mission $(\mathrm{n}=644)$ and Sai Cinza $(\mathrm{n}=734)$ villages. These villages were selected due to population size (together, they represent approximately $25 \%$ of the Munduruku in Pará, of which $37 \%$ claimed they were indigenous to Jacareacanga), and on the fact that they concentrated the largest number of notified TB cases in the last four years, according to data from the Special Indigenous Sanitary District of the Tapajós River.

The sample consisted of 1,213 indigenous individuals, corresponding to $65 \%$ of the eligible study population. To obtain the data, interviews were conducted with the help of a questionnaire that included the following variables: place of residence (village), gender, age group, education, family income, 
type of housing, number of people per household, presence of respiratory symptoms, history of contact with a TB patient, and a BCG vaccine scar.

The screening procedures for active $\mathrm{TB}$ and latent $\mathrm{TB}$ infection followed the recommendations of the National Tuberculosis Control Program (NTCP). Thus, on the occasion of the interview, when identifying persons with respiratory symptoms, the first sputum sample was collected and the participant received instructions on how to collect the second sample the next day, when(s) he woke up. The material was immediately processed at the village health service, using the Ziehl-Neelsen method, and seeded in an Ogawa-Kudoh culture medium. Next, all participants were submitted to the Tuberculin Skin Test (TST), using PPD Rt 23 (Statens Serum Institute, Copenhagen, Denmark), through a $0.1 \mathrm{~mL}$ intradermal injection, corresponding to two tuberculin units, in the middle third of the front part of the left forearm (Arnadottir et al., 1996). Hypersensitivity to the PPD was measured between 48 and 72 hours after inoculation.

The seeded mediums were stored in thermal boxes and forwarded to the Central Laboratory of the State in the capital Belém (referral institution for tuberculosis diagnosis), where they were stored in a bacteriological incubator at $37^{\circ} \mathrm{C}$. Reading was performed weekly, observing the standards for the display of results.

In addition, chest X-rays were taken, with posterior-anterior (PA) incidence for all identified cases of respiratory symptoms and individuals with PPD results $\geq 10 \mathrm{~mm}$. To take the $\mathrm{x}$-rays, a portable device was used due to the adverse conditions in the villages, and expert opinions were issued by a lung specialist according to Den Boon et al., (2005). A radiologist from a Referral Hospital in Health Pulmonology reviewed all tests with suspected and sequelae lesions and signs of other diseases, including the children's x-rays.

To analyze the data, the software Statistical Package for the Social Sciences (SPSS), version 17 was used. The following statistical procedures were applied: $X^{2}$ test, univariate analysis and multivariate associations through logistic regression, adopting a significance level $\alpha=5 \%$ and a $\mathrm{p}$ value $<0.05$, with a $95 \%$ confidence interval. The multivariate analysis only considered the variables that showed a statistically significant association in the univariate analysis. The odds ratio (OD) was used as a measure of association.

Approval for this research was obtained from the Research Ethics Committee of the Nursing Program at Universidade do Estado do Pará and from the National Research Ethics Committee (CONEP) - opinion 116/2010. Authorization was obtained from the Fundação Nacional do Índio to enter indigenous territory - number 0724/2010 and from the Village Heads to collect the data, including signing of the free and informed consent form. 


\section{RESULTS}

In this study, 1,213 indigenous individuals were assessed, 660 of whom were women $(54.4 \%)$ and $632(52.1 \%)$ were under 15 years of age. This age-distribution is representative of the marked population growth among indigenous peoples in Brazil The family income was no more than two minimum wages $(92.4 \%)$, strongly supplemented by assistance programs from the federal government, with $90 \%$ receiving the so-called Bolsa Familia. The participants presented low levels of education, with up to four years of schooling (71.7\%) and 932 people live in homes with no more than two rooms (76.8\%).

Seventy individuals with respiratory symptoms were identified, representing a prevalence rate of $5.8 \%(95 \% \mathrm{CI}=4.6 \%-7.2 \%)$ of the sample; 60 $(85.7 \%)$ of which were over 15 years of age and, among the minors, 4 children between the ages of 7 and 10 were identified. The mean age for respiratory symptom cases was 23.3 years (standard deviation 22.2 years). Among the referred symptoms, coughing and chest pain were the most frequent. 68 people were submitted to direct sputum smear microscopy, using Ziehl-Neelsen staining, in two samples collected on consecutive days, with all results proving negative.

In addition, for each investigated case of respiratory symptoms, two cultures were done in Ogawa-Kudoh medium with positive results in samples from three different patients. The performance rate of the tests was $95,6 \%$, as contamination was found in three of them. The biochemical analysis confirmed one of them as a strain of Mycobacterium tuberculosis, with a prevalence rate of $82.4 / 100,000$ inhabitants. The other two were classified as environmental mycobacteria, although the possibility of transience exists. It was impossible to proceed with the specification of the isolates due to operational aspects.

The positive case for MTB corresponds to a relapse that received earlier treatment and was discharged because of cure. The two identified cases of environmental mycobacteria was contacts with a patient in the family and presented respiratory symptoms and a pulmonary image with multiple lesions. The cases were referred to the local healthcare service for follow-up and clinical investigation.

In total, 219 individuals were examined, corresponding to $75.5 \%$ of cases referred for X-ray. Among the cases referred for X-ray, were 250 people with a PPD result $\geq 10 \mathrm{~mm}$, of which 28 presented respiratory symptoms, as well as 40 people with respiratory symptoms but with a PPD result less than $10 \mathrm{~mm}$. Chest x-rays were taken from 219 people, $40(18.3 \%)$ of whom showed abnormalities, with a predominance of pulmonary nodes (30.6\%) and fibrotic tissue $(12.9 \%)$, considered sequelae. Infiltration was identified in eleven $\mathrm{x}$-rays, one with a bone cavity image (Table 1). 
Table 1. Radiological examination of the chest and lung lesions in the Munduruku population - Para / Brazil, 2011

\begin{tabular}{|c|c|}
\hline Results/pulmonary radiological findings & $\mathrm{N}$ \\
\hline Normal & 179 \\
\hline With changes & 40 \\
\hline \multicolumn{2}{|l|}{ Lesion Types } \\
\hline Nodule & 26 \\
\hline Fibrotic tissue & 16 \\
\hline Infiltrates & 11 \\
\hline Fibrosis & 8 \\
\hline Hyperinsuflation & 5 \\
\hline Veiling & 4 \\
\hline Calcification & 4 \\
\hline Infiltration with cavitation & 1 \\
\hline
\end{tabular}

In total, 1213 tuberculin tests were applied and the prevalence of infection by MTB in the villages studied. Among the total number of tests read $(\mathrm{n}=1135) 22.0 \%(95 \%$ CI $19.7 \%-24.5 \%)$ showed reactions $\geq 10 \mathrm{~mm}$ and $37.4 \%(95 \%$ CI $34.6 \%-40.2 \%)$ showed results up to the $5 \mathrm{~mm}$ cut-off point. The TST reactions $\geq 10 \mathrm{~mm}$ were associated with the variables village, age, gender, contact history, and presence of a BCG vaccine scar.

Among the villages, Nova Karapanatuba showed a greater association (OR adjusted $2.08 p$-value 0.012 95\% CI 1.18-3.69) and an age group over 40 years (OR adjusted $47.80 p$-value $<0.00$ CI 27.25-83.87). A higher chance of LTBI was identified in the male group (OR adjusted $1.86 p$-value $<0.001 \mathrm{CI}$ 1.31-2.64), as well as in the group of people who reported a contact history with TB patients (OR adj $2.38 p$-value $<0.001 \mathrm{CI} 1.53-3.72$ ). In the participants with a BCG scar, the probability of finding people with TST $\geq 10 \mathrm{~mm}$ was 2.36 times higher ( $p$-value 0.017 CI1.16-4.80) than in people with an absent or doubtful BCG scar (Table 2).

\section{DISCUSSION}

The presence of TB was confirmed in all the villages studied, with high disease rates, above averages for Brazil and for the state of Pará. These results are similar to findings in other tribes from the Brazilian Amazon (Basta et al., 2006a; Garnelo et al, 2003; Levino \& Oliveira, 2007; Rios et al., 2013b), and higher than both the national average $(36.0 / 100,000)$ and the average in the state of Pará $(47.3 / 100,000)$ in the same year (http://portalsaude.saude.gov.br/ images/pdf/2014/junhoq23/BE-2012-43-Mar--o---Especial-Tuberculose.pdf). 
Table 2. Logistic models for TST reactions $\geq 10 \mathrm{~mm}$ for the Munduruku indigenous group, Pará State, Brazilian Amazon, 2011.

\begin{tabular}{|c|c|c|c|c|c|c|}
\hline \multirow[t]{2}{*}{ Characteristics } & \multicolumn{3}{|c|}{ Logistic model - Univariate } & \multicolumn{3}{|c|}{ Logistic model - multivariate 2} \\
\hline & OR & $95 \% \mathrm{CI}$ & p-value & $\mathrm{OR}_{\text {adj }}{ }^{*}$ & $95 \% \mathrm{CI}$ & p-value \\
\hline . Village & & & 0.028 & & & $<0.001$ \\
\hline Kato & 1 & & & 1 & & \\
\hline $\begin{array}{l}\text { Missão São } \\
\text { Francisco }\end{array}$ & 0.82 & $0.54-1.23$ & 0.340 & 0.60 & $0.36-0.98$ & 0.042 \\
\hline $\begin{array}{l}\text { Nova } \\
\text { Karapanatuba }\end{array}$ & 1.51 & $0.96-2.38$ & 0.074 & 2.08 & $1.18-3.69$ & 0.012 \\
\hline SaiCinza & 1.06 & $0.70-1.62$ & 0.770 & 1.52 & $0.91-2.56$ & 0.112 \\
\hline . Age & & & $<0.001$ & & & $<0.001$ \\
\hline 2 to 14 years & 1 & & & 1 & & \\
\hline 15 to 39 years & 14.37 & $8.84-23.37$ & $<0.001$ & 15.51 & $9.44-25.47$ & $<0.001$ \\
\hline $\begin{array}{l}40 \text { to } 87 \text { years } \\
\text { Gender }\end{array}$ & 40.29 & $23.69-68.50$ & $<0.001$ & 47.80 & $27.25-83.87$ & $<0.001$ \\
\hline Male & 1.27 & $0.96-1.68$ & 0.097 & 1.86 & $1.31-2.64$ & $<0.001$ \\
\hline $\begin{array}{l}\text { Female } \\
\text { Contact with } \\
\text { tuberculosis } \\
\text { patient }\end{array}$ & 1 & & & 1 & & \\
\hline Yes & 2.38 & $1.71-3.34$ & $<0.001$ & 2.38 & $1.53-3.72$ & $<0.001$ \\
\hline $\begin{array}{l}\text { No or does not } \\
\text { know } \\
\text {. BCG scar }\end{array}$ & 1 & & & 1 & & \\
\hline Present & 1.63 & $0.91-2.93$ & 0.103 & 2.36 & $1.16-4.80$ & 0.017 \\
\hline $\begin{array}{l}\text { Absent or } \\
\text { doubtful }\end{array}$ & 1 & & & 1 & & \\
\hline
\end{tabular}

The poor living conditions observed in the Munduruku villages proved favorable for the transmission of TB. In general, the houses were small, had no natural lighting, and were badly ventilated. Moreover, there was a high concentration of people per household, and low income was reported by the majority of the subjects. This environment is ideal for spreading many kinds of infectious diseases, particularly tuberculosis (Ruffino-Netto, 2002).

It has been suggested that indigenous people are uncooperative in sputum smear collection (Can, 2007), a statement we believe only covers the inefficiency of health services offered to indigenous people. In order to counter this allegation, training was offered to laboratory technicians and guidance to 
all patients before collection. Despite this effort, no positive results were found on the direct sputum smear microscopy.

The confirmation of MTB in the sample culture highlighted the importance of this test to diagnose TB, mainly in indigenous populations, and highlights the need to implement it in the service routine, in compliance with the standards of the NTCP (Ministério da Saúde, 2011). Nevertheless, the X-rays confirmed both active disease lesions and sequelae of previous infections. The confirmed case of MTB showed an X-ray image with infiltration in the upper right lobe, supporting the clinical and laboratory diagnosis. In the cases of possible non-tuberculous mycobacteria, X-rays showed multiple lesions in both lungs.

In the assessment of LTBI an association was identified with the village of residence, adult age, contact history, and presence of a BCG vaccine scar, similar to findings in other tribes (Basta et al., 2006a; Basta et al., 2010a; Rios et al., 2013a). Villagers from Nova Karapanatuba presented a higher risk of latent tuberculosis compared to the residents of Katõ, perhaps due to proximity with the urban center of Jacareacanga, enabling frequent visits to the local stores, presenting opportunities for more intense contact with $M$. tuberculosis. In addition, in $78 \%$ of the tuberculin skin tests read, the measures were $<10 \mathrm{~mm}$. Some TST reactions between 5 and $10 \mathrm{~mm}$ might have been related to infection by atypical mycobacteria and BCG rather than to M. tuberculosis, given the high BCG vaccine coverage in the participants, corresponding to about $91 \%(807 / 885)$.

This study is limited by the choice of the most populous villages, representing a convenience sample. As TB is transmitted through direct contact with an infected individual, villages with less contact may present an epidemiologic setting different from that described here.

Our findings support high disease rates, higher than the rates for the state of Pará and the nation as a whole, but similar to findings from studies conducted among other indigenous groups (Basta et al., 2004; Bóia et al., 2009; Croda et al., 2012; Coimbra Jr \& Basta, 2007; Marques \& Cunha, 2003; Melo et al., 2012), although these studies show great variations. These rates may become even higher due to the social vulnerability of the indigenous people and the operational fragmentation in the disease control actions.

Health practices in the villages require better qualification, including the systematic search for respiratory symptoms and contact surveillance. Resources to confirm diagnosis are required and transportation logistics enabling access to these resources need to be resolved.

In addition, multidisciplinary health teams should receive training that values cultural background to improve communication with the indigenous people, enabling qualified care practices, and supporting health action planning from the perspective of the local inhabitants and their environment (Nogueira et al., 2015). TB control in indigenous populations depends on prioritising 
health policies and actions focused on specific problems, according to the way of life in the villages.

Health authorities in Brazil must urgently take measures to cope with these factors to better control the TB epidemic and avoid unnecessary suffering among the indigenous population. A service network must be set up to address the key points regarding $\mathrm{TB}$, offering effective primary health care in the villages and specialized clinical and diagnostic care. These measures can control TB and enhance the quality of life in this population.

\section{ACKNOWLEDGEMENTS}

This study was granted by public notice n. 013/2009, Research for the Brazilian Unified Health System (SUS): Shared Management in Health of the Research Program for the Unified Health System (PPSUS, MS/CNPq/Fapespa/Sespa).

\section{REFERENCES}

1. Arnadottir T, Rieder HL, Trébucq A, Waaler HT. Guidelines for conducting tuberculin skin test surveys in high prevalence countries. Tuber Lung Dis 77: 1-19, 1996.

2. Basta PC, Coimbra Jr CEA, Escobar AL, Santos RV. Aspectos epidemiológicos da tuberculose na população indígena Suruí, Amazônia, Brasil. Rev Soc Bras Med Trop 37: 338-342, 2004.

3. Basta PC, Oelemann MAC, Oelemann WMR, Fonseca LS, Coimbra Jr CEA. Detection of Mycobacterium tuberculosis in sputum from Suruí Indian subjects, Brazilian Amazon. Mem Inst Oswaldo Cruz 101: 581-584, $2006 \mathrm{a}$.

4. Basta PC, Coimbra CE Jr, Camacho LA, Santos RV. Risk of tuberculous infection in an indigenous population from Amazonia, Brazil. Int J Tuberc Lung Dis 10:1354-1359, $2006 \mathrm{~b}$.

5. Basta PC, Coimbra Jr CEA, Welch Jr, Alves LCC, Santos RV, Camacho LAB. Tuberculosis among the Xavante Indians of the Brazilian Amazon: An epidemiological and ethnographic assessment. Ann Hum Biol 37: 643-657, 2010a.

6. Basta PC, Rios DPG, Alves LCC, SantAnna CC, Coimbra Junior CE. Estudo clínicoradiológico de crianças e adolescentes indígenas Suruí, Região Amazônica. Rev Soc Bras Med Trop 43: 719-722, $2010 \mathrm{~b}$.

7. Bóia MN, Carvalho-Costa FA, Sodré FC, Porras-Pedroza BE, Faria EC, Magalhães GAP, Silva IM, Coura JR .Tuberculose e parasitismo intestinal em população indígena na Amazônia brasileira. Rev Saude Publica 43: 176-178, 2009.

8. Brasil, Ministério da Saúde. Disponível em: http://portalsaude.saude.gov.br/images/pdf/2014/ julho/23/BE-2012-43-Mar--o---Especial-Tuberculose.pdf Secretaria de Vigilância em Saúde. Boletim Epidemiológico. Acesso em 09 de nov 2015.

9. Can Commun Dis Rep. Housing conditions that serve as risk factors for tuberculosis infection and disease. An Advisory Committee Statement (ACS). Can Commun Dis Rep 33: 1-13, 2007.

10.Coimbra CE Jr, Basta PC. The burden of tuberculosis in indigenous people in Amazonia, Brazil. Trans R Soc Trop Med Hyg 101: 635-636, 2007.

11.Croda MG, Trajber Z, Lima RC, Croda J. Tuberculosis control in a highly endemic indigenous community in Brazil. Trans R Soc Trop Med Hyg 106: 223-229, 2012.

12.Den Boon S, Bateman ED, Enarson DA, Borgdorff MW, Verver S, Lombard CJ, Irusen E, Beyers N, White NW. Development and evaluation of a new chest radiograph reading and 
recording system for epidemiological surveys of tuberculosis and lung disease. Int J Tuberc Lung Dis 9: 1088-1096, 2005.

13. Escobar AL, Coimbra CE Jr, Camacho LA, Santos RV. Tuberculin reactivity and tuberculosis epidemiology in the Paakanova (Wari')Indians of Rondônia, South western Brazilian Amazon. Int J Tuberc Lung Dis 8: 45-51, 2004.

14. Garnelo L, Macedo G, Brandão LC. Os povos indígenas e a construção das políticas de saúde no Brasil. Brasília, DF: Organização Pan-Americana de Saúde, 2003.

15. Hino P, Santos CB dos, Villa TCS, Bertolozzi MR, Takahashi RF. O controle da tuberculose na perspectiva da vigilância da saúde. Escola Anna Nery 15: 417-421, 2011.

16.Instituto Brasileiro de Geografia e Estatística. IBGE, 2010. Disponível em: "http://www.sidra. ibge.gov.br/bda/tabela/protabl.asp?c=3175\&z=cd\&o=7\&i=P"http://www.sidra.ibge.gov.br/ bda/tabela/protabl.asp? $\mathrm{c}=3175 \& \mathrm{z}=\mathrm{cd} \& \mathrm{o}=7 \& \mathrm{i}=\mathrm{P}$, acessado em 5 de junho de 2014).

17. Levino A, Oliveira RM. Tuberculose na população indígena de São Gabriel da Cachoeira, Amazonas, Brasil. Cad de Saúde Pública 23: 1728-1732, 2007.

18. Marques AMC, Cunha RV. A medicação assistida e os índices de cura de tuberculose e de abandono de tratamento na população indígena Guarani-Kaiwá no município de Dourados, Mato Grosso do Sul, Brasil. Cad Saude Publica 19: 1405-1411, 2003.

19. Marques AMC, Pompilio MA, Santos SD, Garnês SJ, Cunha RV. Tuberculose em indígenas menores de 15 anos, no Estado de Mato Grosso do Sul. Rev Soc Bras Med Trop 43: 700-704, 2010 .

20. Melo TEMP, Resendes APC, Souza-Santos R, Basta PC. Distribuição espacial e temporal da tuberculose em indígenas e não indígenas de Rondônia, Amazônia Ocidental, Brasil. Cad Saude Publica 28: 267-280, 2012.

21. Ministério da Saúde. Secretaria de Vigilância em Saúde. Boletim Epidemiológico. Disponível em: "http://portalsaude.saude.gov.br/images/pdf/2014/maio/29/BE-2014-45--2--tb.pdf"http:// portalsaude.saude.gov.br/images/pdf/2014/maio/29/BE-2014-45--2--tb.pdf. Acesso em 09 de nov 2015.

22.Ministério da Saúde. Secretaria de Vigilância em Saúde. Manual de Recomendações para o Controle da Tuberculose no Brasil, 2011.

23. Nogueira LMV, Teixeira E, Basta PC, Motta MCS. Therapeutic itineraries and explanations for tuberculosis: an indigenous perspective. Rev Saúde Pública 49: 96, 2015.

24.Ramos A. Munduruku. Instituto Socioambiental. 2003, Disponível em "http://pib.sociambiental. org/pt/povo/munduruku/print"http://pib.sociambiental.org/pt/povo/munduruku/print, accessed on March 8, 2009.

25.Rios DPG, Malacarne J, Alves LCC, SantAnna CC, Camacho LAB, Basta PC. Tuberculose em indígenas da Amazônia brasileira: estudo epidemiológico na região do Alto Rio Negro. Rev Panam Salud Publica 33: 22-29, 2013.

26.Ruffino-Netto A. Tuberculose: a calamidade negligenciada. Rev Soc Bras Med Trop. 35: 51-58, 2002.

27.Santos SC, Marques AMC, Oliveira RL, Cunha RV. Diagnóstico da tuberculose em indígenas menores de quinze anos por meio de um sistema de pontuação em Mato Grosso do Sul. J Bras Pneumol 39: 84-91, 2013.

28.Sousa AO, Salem JI, Lee FK, Verçosa MC, Cruaud P, Bloom BR, Lagrange PH, David HL. An epidemic of tuberculosis with a high rate of tuberculin anergy among a population previously unexposed to tuberculosis, the Yanomami Indians of the Brazilian Amazon. Proc Natl Acad Sci USA 94: 13227-13232, 1997.

29.Yuhara LS, Sacchi FPC, Croda J. Impact of Latent Infection Treatment in Indigenous Populations. PLOS ONE 8: e71201, 2013. 